\title{
Peran Kenikmatan Berbelanja dalam Memediasi Kepribadian Terhadap Impulse Buying
}

\author{
Adelia Christina Purnasari ${ }^{1}$ \\ Ni Made Rastini 2 \\ Fakultas Ekonomi dan Bisnis Universitas Udayana, Bali, Indonesia \\ e-mail: nimaderastini@yahoo.co.id
}

\begin{abstract}
Abstrak
Penelitian ini bertujuan untuk mengetahui peran kenikmatan berbelanja dalam memediasi kepribadian terhadap impulse buying pada Stradivarius Beachwalk di Kabupaten Badung. Metode penentuan sampel yang digunakan dalam penelitian ini adalah teknik purposive sampling dengan sampel sebanyak sebanyak 125 responden.Teknik analisis data yang digunakan adalah Path Analysis. Hasil penelitian ini menunjukkan bahwa kepribadian berpengaruh positif dan signifikan terhadap kenikmatan berbelanja di Stradivarius Beachwalk Kabupaten Badung. Kepribadian berpengaruh positif dan signifikan terhadap impulse buying di Stradivarius Beachwalk Kabupaten Badung. Kenikmatan berbelanja berpengaruh positif dan signifikan terhadap impulse buying di Stradivarius Beachwalk Kabupaten Badung. Serta kenikmatan berbelanja berpengaruh positif dan signifikan sebagai variabel yang mampu memediasi kepribadian terhadap impulse buying di Stradivarius Beachwalk Kabupaten Badung. Sehubungan dengan hasil dan pembahasan dalam penelitian ini, maka diharapkan pihak pengelola Stradivarius lebih memberikan rasa nyaman saat konsumen berbelanja dan hendaknya lebih memperhatikan kenyaman suhu di dalam ruangan.
\end{abstract}

Kata kunci: kepribadian, kenikmatan berbelanja, impulse buying

\section{Pendahuluan}

Perkembangan bisnis saat ini diwarnai dengan berbagai macam persaingan dalam segala bidang. Perusahaan berlomba-lomba memberikan pelayanan dan kualitas yang terbaik bagi produknya.Salah satunya bisnis pada bidang fashion. Perkembangan dunia bisnis selalu berkembang setiap saat. Berdasarkan situasi ekonomi seperti saat ini, perusahaan harus semakin sadar terhadap apa yang konsumen butuhkan dalam berbelanja, termasuk juga dengan trend fashion di kalangan anak muda di Bali. Perusahaan dalam bidang fashion berlomba-lomba menciptakan produk yang dapat menarik minat konsumen. Perkembangan merek- merek fashion di Indonesia relatif cukup baik dan dinamis, walaupun harus bersaing secara ketat dengan merek-merek asing. Berdasarkan hal ini, perusahaan harus selalu meningkatkan strategi pemasarannya untuk menarik konsumen membeli produknya.

Perusahaan memiliki banyak pilihan strategi yang bisa dugunakan untuk memperkenalkan produknya. Salah satunya adalah dengan membentuk identitas produk melalui merek. Banyak konsumen yang jika melakukan pembelian hanya untuk mendapatkan produk dari suatu merek ternama.Tidak jarang konsumen rela mengeluarkan biaya besar hanya untuk membeli produk dari suatu merek yang sudah terkenal. Strategi lain yang biasa digunakan perusahaan adalah, dengan menciptakan suasana gerai yang nyaman. Tujuannya tentu untuk menarik minat calon konsumen untuk datang dan berbelanja. Konsumen yang akan melakukan pembelian di suatu toko terbagi menjadi dua kategori. Konsumen dapat 
INOBIS: Jurnal Inovasi Bisnis dan Manajemen Indonesia

Volume 1, Nomor 3, Juni 2018

\section{Adelia Christina Purnasari; Ni Made Rastini}

melakukan pembelian secara terencana dan ada yang melakukan pembelian dengan tidak terencana. Konsumen yang melakukan pembelian secara terencana, cenderung akan membeli apa yang sudah direncanakan sebelumnya secara rasional. Berbeda halnya dengan yang melakukan pembelian tidak terencana(Impulse Buying). Impulse buying lebih menekankan pembelian secara emosional tanpa memikirkan baik buruknya produk yang dibeli.Akhirnya konsumen cenderung out of control saat membeli secara tidak terencana (Mohan et al., 2013).Saad dan Metawie (2015), menyatakan bahwa impulse buying dapat dipengaruhi oleh keadaan internal seseorang atau faktor lingkungan yang dialami oleh seseorang. Perilaku pembelian yang direncanakan, impulse buying lebih meningkatkan gairah, dilakukan secara tidak direncanakan dan perilaku pembeliannya lebih menarik (Kacen dan Lee, 2002). Saad dan Metawie (2015) menyatakan keputusan pembelian impulsif memiliki beberapa faktor diantaranya kepribadian, harga diri, kenikmatan, dan impulsivity. Upaya untuk memuaskan harga diri dan kebutuhan aktualisasi diri mendorong konsumen untuk melakukan pembelian secara impulsif (Hausman,2000).

Keputusan pembelian seperti ini dipengaruhi oleh sikap kepribadian konsumen. Kepribadian seseorang salah satunya dipengaruhi oleh trend yang terjadi di sekitarnya. Penelitian yang dilakukan oleh (Harmancioglu et al.,2009) menyebutkan bahwa konsumen perlu memenuhi kebutuhan harga diri mereka dan berkeinginan mendapatkan rasa hormat dari orang lain, yang akan mendorong niat membeli mereka. Bagi sebagian orang akan merasa bahagia saat setelah melakukan kegiatan berbelanja. Sebagian konsumen berbelanja hanya untuk memenuhi kebutuhan kepribadian hedonisnya (Saad dan Metawie, 2015). Kepribadian setiap konsumen berbeda-beda, hal inilah yang menjadi tugas pemasar untuk bisa memahami dan mengkategorikan kepribadian seseorang agar dapat mengetahui apa yang dibutuhkan konsumen. Salman (2014) menyebutkan karakteristik produk bukan satu-satunya faktor yang menyebabkan pembelian, karakteristik konsumen juga memiliki peran penting dalam hal pembelian.

Faktor kenikmatan berbelanja (shopping enjoyment) juga menjadi faktor penting dalam pengambilan keputusan membeli secara impulsif. Menurut Beatty dan Ferrell (1998) shopping enjoyment adalah keadaan yang efektif mendorong pembelian secara impulsif. Studi ini juga menyimpulkan bahwa seseorang yang menikmati berbelanja akan meningkatkan niat pembelian secara impulsif. Penelitian yang dilakukan (Hart et al., 2006) menyebutkan jenis kelamin seserorang juga mempengaruhi shopping enjoyment seseorang. Penelitian ini juga menegaskan saat seseorang merasakan kenikmatan berbelanja, maka cenderung akan melakukan kegiatan berbelanja. Semakin baik store atmosphere yang diberikan pemasar, maka konsumen akan semakin merasakan shopping enjoyment saat berbelanja (Bitner, 1992).

Penelitian ini berfokus pada perusahaan di bidang fashion, karena akhir- akhir ini perkembangan trend fashion tumbuh dan bersaing begitu dinamis, khususnya di Bali. Pertumbuhan dan persaingan tersebut nantinya akan diiringi oleh kemampuan pemasar dalam berinovasi. Fenomena ini diperlukan kreativitas, ide-ide baru dan kemampuan seorang pemasar yang selalu update dengan perkembangan dunia fashion. Pemasar juga diharapkan dapat mengelompokan kepribadian konsumen yang karakteristiknya beranekaragam. Berdasarkan teori yang telah dikemukakan, timbul keinginan untuk melakukan penelitian di salah satu mall terbesar yang ada di Bali, khususnya di Kabupaten Badung.Tempat yang di design mewah dan berkelas membuat masyarakat kelas menengah dan kelas atas datang untuk berbelanja di tempat tersebut.Dukungan produk-produk dengan brand ternama disajikan di dalam mall tersebut.

Stradivarius adalah salah satu perusahaan yang bergerak di bidang pakaian yang 
INOBIS: Jurnal Inovasi Bisnis dan Manajemen Indonesia

Volume 1, Nomor 3, Juni 2018

Adelia Christina Purnasari; Ni Made Rastini

terletak di dalam mall Beachwalk. Suasana toko yang nyaman dan model pakaian yang selalu mengikuti selera pasar, membuat Stradivarius menjadi salah satu pilihan toko yang tepat untuk berbelanja.

Tujuan yang ingin dicapai melalui penelitian ini adalah1) untuk menjelaskan pengaruh kepribadian terhadap kenikmatan berbelanja di Stradivarius, 2) untuk menjelaskan pengaruh kepribadian terhadap Impulse Buying di Stradivarius, 3) untuk menjelaskan pengaruh kenikmatan berbelanja terhadap Impulse Buying di Stradivarius, 4) untuk menjelaskan peran mediasi kenikmatan berbelanja pada pengaruh kepribadian terhadap Impulse Buying di Stradivarius.

\section{Kajian Teori dan Hipotesis}

Berdasarkan penelitian dari Saad dan Metawie (2015) menyatakan secara keseluruhan, hasil penelitian menunjukkan bahwa dua faktor kepribadian, yakni kegembiraan dan harga diri secara signifikan berpengaruh positif dengan kenikmatan berbelanja (shopping enjoyment). Kepribadian individu seperti gender berpengaruh positif terhadap kenikmatan berbelanja (Hart et al., 2006). Faktor kepribadian seperti lingkungan sosial individu berpengaruh positif dan signifikan terhadap kenikmatan yang dirasakan pada saat berbelanja di tempat tertentu (Shen,2012).

H1: $\quad$ Kepribadian berpengaruh positif dan signifikan terhadap kenikmatan berbelanja.

Berdasarkan penelitian yang dilakukan oleh Sun dan Wu (2011) menunjukkan bahwa pelanggan yang memiliki kepribadian yang terobsesi dengan sifat hedonis diyakini memiliki pengaruh positif terhadap impulse buying.Chuah dan Gan (2015) menyebutkan adanya pengaruh positif antara kepribadian terhadap impulse buying. Penelitian yang dilakukan oleh Mathai dan Haridas (2014) mengungkapkan bahwa ada hubungan yang signifikan antara kepribadian dan impulse buying, karena ada beberapa nilai yang signifikan kecuali untuk variabel dalam khasus produk dengandiskon.

H2: Kepribadian berpengaruh positif dan signifikan terhadap Impulse Buying.

Penelitian yang dilakukan Rukhamai (2015) menyebutkan kenikmatan berbelanja berpengaruh positif dan signifikan terhadap keputusan pembelian.Menurut Kwek et al. (2010) faktor kenikmatan merupakan sebuah prediksi yang kuat dan memiliki pengaruh positif terhadap Impulse Buying. Konsumen yang menikmati suasana saat sedang berbelanja, akan membangun sikap yang positif terhadap pembelian (Murti, 2012). Kenikmatan berbelanja berpengaruh positif dan signifikan terhadap impulse buying (Hoch dan Lowenstein, 1991). Kenikmatan berbelanja cenderung memiliki pengaruh positif dan signifikan terhadap pembelian (Mohan et al., 2013). Konsumen yang merasakan kenikmatan berbelanja cenderung menunjukkan sikap yang positif untuk melakukan impulse buying (Kim,2010).

H3:Kenikmatan berbelanja berpengaruh positif dan signifikan terhadap Impulse Buying.

Hasil penelitian yang telah dilakukan oleh Saad dan Metawie (2015) yang berjudul "Store Environment, Personality Factors and Impulse Buying Behavior in Egypt: The Mediating Roles of Shop Enjoyment and Impulse Buying Tendencies" mengatakan bahwa faktor kepribadian seperti kegembiraan dan harga diri serta lingkungan toko secara positif dan signifikan terkait dengan perilaku pembelian impulsif. Pembelian secara impulsif muncul untuk memediasi hubungan antara faktor kepribadiandan Impulse Buying behavior.Kenikmatan berbelanja (shopping enjoyment) berperan memediasi hubungan 
INOBIS: Jurnal Inovasi Bisnis dan Manajemen Indonesia

Volume 1, Nomor 3, Juni 2018

\section{Adelia Christina Purnasari; Ni Made Rastini}

antara kepribadian dan pembelianimpulsif.

H4: Kepribadian berpengaruh positif dan signifikan terhadap Impulse Buying dengan mediasi kenikmatan berbelanja.

\section{Gambar 1. Kerangka Konsep Penelitian}

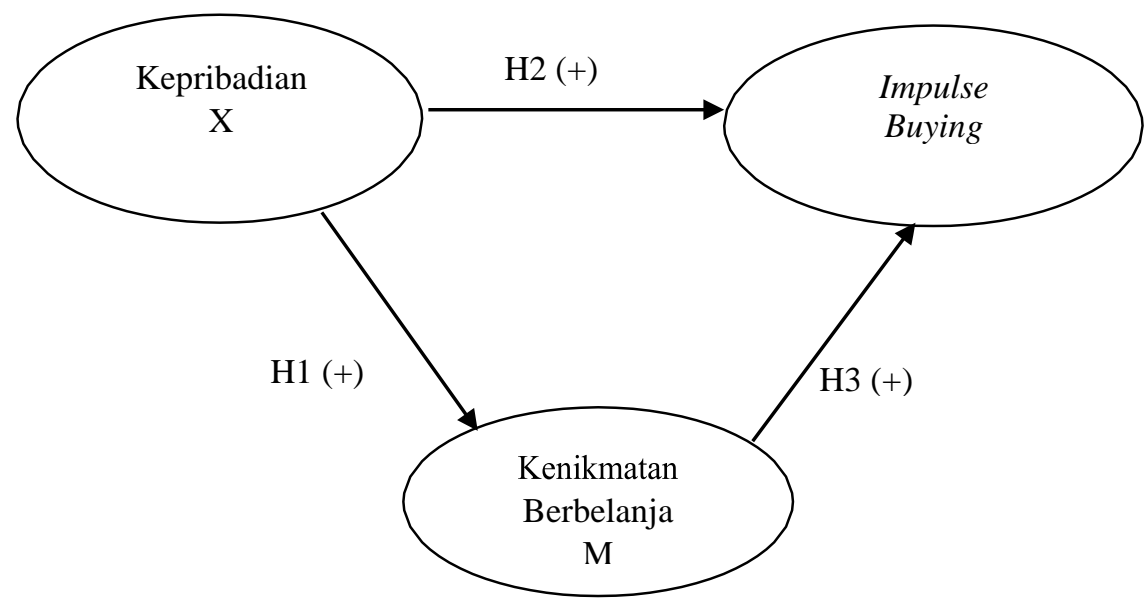

Sumber: Saad dan Metawie, 2015

\section{Metode Penelitian}

Jenis penelitian ini menggunakan desain penelitian asosiatif, dimana penelitian asosiatif adalah penelitian yang bertujuan untuk mengetahui pengaruh antara dua variabel atau lebih. Dalam penelitian ini pengaruh kepribadian terhadap impulse buying dengan kenikmatan berbelanja sebagai variabel pemediasi.

Penelitian ini dilakukan di Stradivarius Beachwalk yang beralamat di Jalan Pantai Kuta, Kabupaten Badung.Lokasi ini dipilih karena Kuta adalah pusat pariwisata yang sangat terkenal dan Beachwalk adalah salah satu mall terbesar di kawasan Kabupaten Badung, yang mayoritas konsumennya adalah remaja hingga dewasa.Berbeda dengan konsep mall pada umumnya, mall ini memiliki disain unik dengan udara terbuka, yang bernuansa tradisi Bali lengkap dengan alang- alang dan tanaman tropis. Stradivarius adalah salah satu gerai yang ada di dalam kawasan mall Beachwalk, yang merupakan gerai yang cukup ramai dikunjungi karena kenyaman dan produk yang ditawarkannya. Terletak di tempat yang strategis pada mall tersebut memudahkan konsumen untuk menemukannya.Pemilihan lokasi penelitian juga karena belum adanya penelitian yang sejenis yang dilakukan di StradivariusBeachwalk.

Variabel eksogen di dalam penelitian ini adalah variabel kepribadian (X). Kepribadian merupakan sifat-sifat yang dapat mempengaruhi cara konsumen merespon kapan, dimana, dan bagaimana mereka mengkonsumsi jasa atau produk tertentu. Kepribadian seseorang mempengaruhi keputusannya untuk memilih atau tidak memilih terhadap jasa yang ditawarkan perusahaan (Fausiana dan Hamid, 2013).Indikator yang digunakan dalam penelitian ini mengacu pada (Phau dan Sari, 2004) dan telah dimodifikasi sesuai kebutuhan penelitian, yang terdiri dari percaya diri.Percaya diri adalah kepercayaan konsumen pengguna produk Stradivarius, dalam hal ini dibagi menjadi 1) mendapat perhatian, 2) merasa berbeda, 3) percaya diri, 4) konservatif, 5) ketegasan.

Variabel mediasi di dalam penelitian ini adalah variabel kenikmatan berbelanja (M). 
INOBIS: Jurnal Inovasi Bisnis dan Manajemen Indonesia

Volume 1, Nomor 3, Juni 2018

\section{Adelia Christina Purnasari; Ni Made Rastini}

Beatty dan Ferrell (1998) mendefinisikan kenikmatan berbelanja sebagai kesenangan yang diperoleh dalam proses berbelanja. Penelitian yang dilakukan oleh Pujiastuti (2009) dan telah dimodifikasi sesuai dengan kebutuhan penelitian, maka indikatornya sebagai berikut 1) penempatan barang, 2) alunan musik, 3) suhu ruangan, 4) penerangan.

Variabel endogen di dalam penelitian ini adalah variabel Impulse Buying (Y).Impulse Buying merupakan salah satu dari perilaku konsumen dalam menentukan suatu keputusan pembelian (Sharma et al., 2010). Adapun indikator Impulse Buying yang telah disesuaikan dengan kebutuhan penelitian mengacupada penelitian Rook dalam (Engel et al., 1995:203) adalah sebagai berikut 1) spontanitas, 2) intensitas, 3) stimulasi, 4) akibat.

Populasi dalam penelitian ini adalah seluruh konsumen yang pernah berbelanja di Stradivarius Beachwalk. Sampel yang dipilih dalam penelitian ini menggunakan teknik purposive sampling yaitu teknik penentuan sampel dengan pertimbangan 1) konsumen yang berkewarganegaan Indonesia, 2) konsumen yang memiliki usia minimal 17 tahun dikarenakan pada usia ini dianggap sudah mampu menjawab kuesioner dengan baik, 3) konsumen yang telah menyelesaikan pendidikan terakhir SMP dikarenakan pada pendidikan ini dianggap sudah dapat memahami isi dari kuisioner, 4) konsumen yang pernah berbelanja secara tidak terencana (Impulse Buying) di Stradivarius Beachwalk dari tahun 2012-2016. Penelitian ini menggunakan sampel sebanyak 125responden.

Metode pengumpulan data yang digunakan dalam penelitian ini adalah kuisioner dengan 5 skaal likert, dimana 1 menunjukan sangat tidak setuju dan 5 menunjukan sangat setuju.

Teknik analisis yang digunakan pada penelitian ini berupa teknik analisis jalur (path analysis).Utama (2009:134) mendefinisaikan analisis jalur adalah perluasan dari analisis regresi linear berganda dalam memperkirakan hubungan kausalitas antar variabel yang berjenjang yang telah ditetapkan berdasarkan teori.Berdasarkan model penelitian maka diagram jalur dalam penelitian ini dapat disajikan pada Gambar 2.

Gambar 2. Diagram Jalur Penelitian

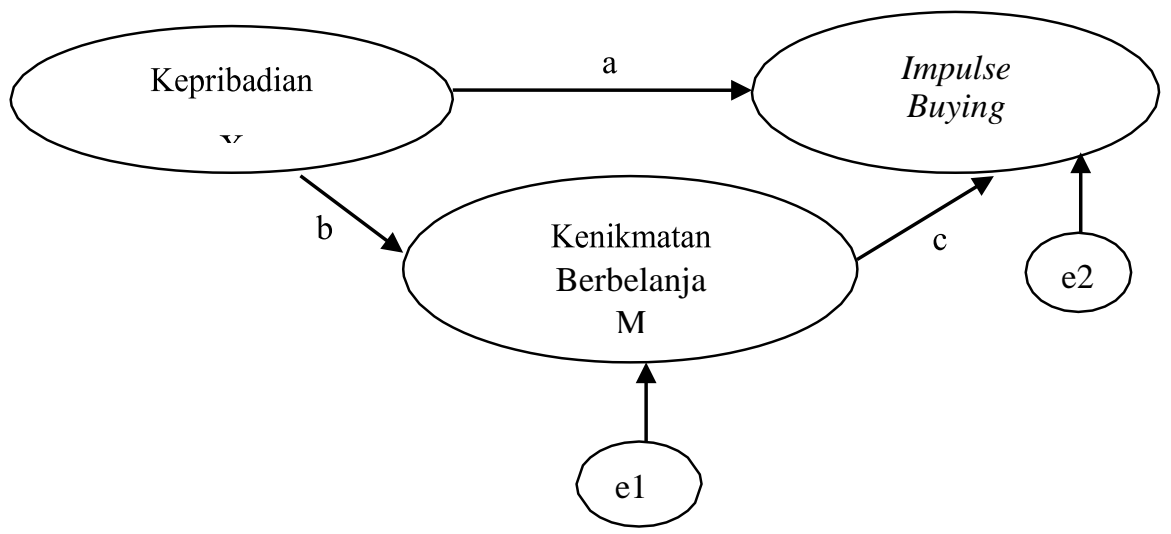

Sumber: data primer diolah,2017

Hubungan antar variabel teoritis dapat dirumuskan kedalam model persamaan struktural dalam rumus 1 dan 2 serta gambar model analisis jalur penelitian dalam Gambar2.

Substruktur 1 adalah $\mathrm{M}=\rho 1 \mathrm{X}+\mathrm{e} 1$

Keterangan :

$\mathrm{X} \quad=$ Kepribadian

$\mathrm{M} \quad=$ Kenikmatan berbelanja 
INOBIS: Jurnal Inovasi Bisnis dan Manajemen Indonesia

Volume 1, Nomor 3, Juni 2018

\section{Adelia Christina Purnasari; Ni Made Rastini}

$1=$ Koefisien regresi variabel kepribadian berpengaruh langsung terhadap

kenikmatan berbelanja

$\mathrm{e} \quad=$ Error of term atau variabel pengganggu

Substruktur 2 adalah $Y=\rho 2 X+\rho 3 M+e 2$

Keterangan :

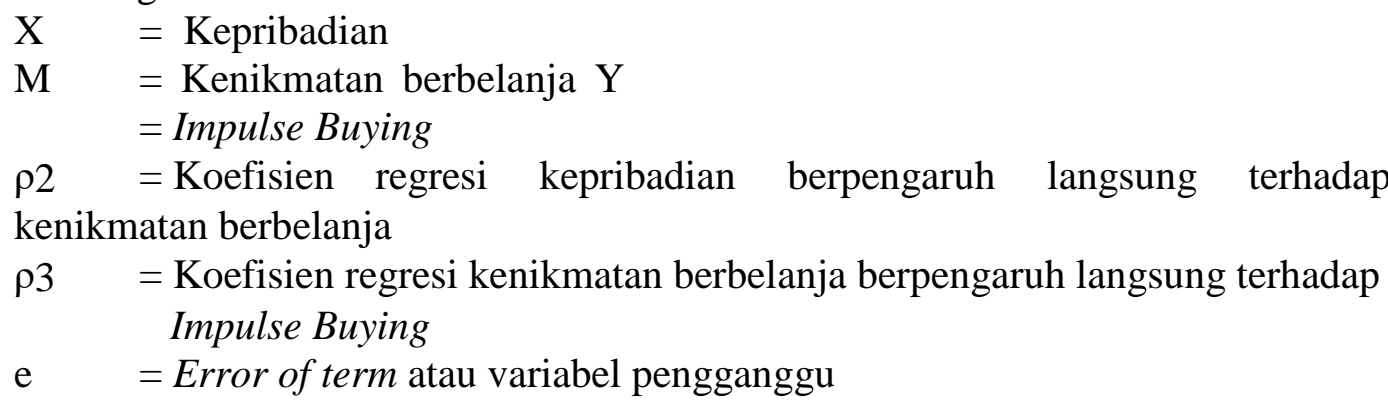

Pengujian hipotesis dalam penelitian ini dilakukan dengan menggunakan dua pengujian yaitu untuk melihat pengaruh langsung dan juga pengaruh tidak langsung. Pengujian pengaruh langsung meliputi pengaruh kepribadian (X) terhadap kenikmatan berbelanja (M) ditunjukkan oleh koefisien jalur b, pengaruh langsung kepribadian (X) terhadap impulse buying (Y) ditunjukkan oleh koefisien jalur a, dan kenikmatan berbelanja(M) terhadap impulse buying $(\mathrm{Y})$ ditunjukkan oleh koefisien jalur c.

Pengujian hipotesis pengaruh tidak langsung atau variabel mediasi dilakukan dengan prosedur uji sobel (sobel test).Uji sobel digunakan untuk menguji kekuatan pengaruh tidak langsung variabel kepribadian (X) terhadap variabel impulse buying (Y) melalui variabel kenikmtan berbelanja $(\mathrm{M})$. Pengaruh tidak langsung variabel kepribadian (X) terhadap variabel impulse buying (Y) melalui variabel kenikmatan berbelanja (M) dihitung dengan cara mengalikan koefisien jalur X terhadap $\mathrm{M}$ (a) dengan koefisien jalur M terhadap $\mathrm{Y}$ (b) atau ab. Standar error koefisien a dan b ditulis dengan $\mathrm{S}_{\mathrm{a}}$ dan $\mathrm{Sb}$, besarnya standar error tidak langsung (indirect effect) Sab. Standar error tidak langsung (indirect effect) Sab dihitung dengan rumus berikut:

$$
\mathrm{Sab}=\ldots \ldots \sqrt{b^{2} s a^{2}+a^{2} s b^{2}+s a^{2} s b^{2}}
$$

Keterangan :

$\mathrm{a}=$ koefisisen regresi dari variabel independen $(\mathrm{X})$ terhadap variabel moderator(M)

$\mathrm{Sa}=\quad$ Standar eror dari a

$\mathrm{b}=$ koefisien regresi dari variabel moderator $(\mathrm{M})$ terhadap variabel dependen $(\mathrm{Y})$

$\mathrm{Sb}=\quad$ Standar eror dari $\mathrm{b}$

\section{Hasil dan Pembahasan}

Uji validitas dikatakan sebagai ketepatan atau kecepatan suatu instrument dalam mengukur apa yang ingin diukur (Priyanto, 2010: 90). Uji validitas biasanya digunakan untuk mengetahui kuisioner yang valid dan dapat digunakan (Anshari, 2013). Hasil uji validitas pada Tabel 1 menunjukkan bahwa seluruh variabel memiliki nilai koefisien korelasi dengan skor total seluruh item pernyataan lebih besar dari 0,30. Hal ini 
INOBIS: Jurnal Inovasi Bisnis dan Manajemen Indonesia

Volume 1, Nomor 3, Juni 2018

Adelia Christina Purnasari; Ni Made Rastini

menunjukkan bahwa butir-butir pernyataan dalam instrument penelitian tersebut valid.

Tabel 1. Hasil Uji Validitas

\begin{tabular}{|c|c|c|c|c|}
\hline No & Variabel & $\begin{array}{l}\text { Item } \\
\text { Pernyataan }\end{array}$ & $\begin{array}{l}\text { Korelasi } \\
\text { Item Total }\end{array}$ & Keterangan \\
\hline \multirow[t]{5}{*}{1} & Kepribadian (X) & $\mathrm{X} 1$ & 0,851 & Valid \\
\hline & & $\mathrm{X}_{2}$ & 0,840 & Valid \\
\hline & & X3 & 0,711 & Valid \\
\hline & & X4 & 0,817 & Valid \\
\hline & & $\mathrm{X} 5$ & 0,826 & Valid \\
\hline \multirow[t]{4}{*}{2} & KenikmatanBerbelanja (M) & M1 & 0,777 & Valid \\
\hline & & M2 & 0,768 & Valid \\
\hline & & M3 & 0,885 & Valid \\
\hline & & M4 & 0,881 & Valid \\
\hline \multirow[t]{4}{*}{3} & Impulse Buying (Y) & Y1 & 0,799 & Valid \\
\hline & & $\mathrm{Y}_{2}$ & 0,862 & Valid \\
\hline & & Y3 & 0,861 & Valid \\
\hline & & Y4 & 0,883 & Valid \\
\hline
\end{tabular}

Sumber: Hasil olahan SPSS, 2017

Pengujian reliabilitas menunjukkan sejauh mana suatu alat pengukur dapat dipercaya atau dapat diandalkan. Hasil uji reliabilitas yang disajikan dalam Tabel2 menunjukkan bahwa ketiga instrumen penelitian yaitu Kepribadian, Kenikmatan Berbelanja dan Impulse Buying memiliki koefisien Cronbach's Alpha lebih dari 0,60. Hal ini dapat dikatakan bahwa semua instrumen reliabel sehingga dapat digunakan untuk melakukan penelitian.

Tabel 2. Hasil Uji Reliabilitas

\begin{tabular}{clll}
\hline No. & Variabel & Cronbach's Alpha & Keterangan \\
\hline 1 & Kepribadian $(\mathrm{X})$ & 0,865 & Reliabel \\
2 & Kenikmatan Berbelanja (M) 0,843 & Reliabel \\
3 & Impulse Buying $(\mathrm{Y})$ & 0,871 & Reliabel \\
\hline
\end{tabular}

Sumber: Hasil olahan SPSS, 2017

Uji Kaiser Meyer Olkin digunakan untuk mengetahui kecukupan sampel. Analisis faktor dianggap layak jika besaran KMO memiliki nilai minimal 0,5. Hasil uji yang ditunjukkan Tabel 3 memperlihatkan semua variabel memiliki KMO > 0,5. Kesimpulannya bahwa masing-masing variabel memiliki kecukupan sampel untuk analisis faktor.

Tabel 3.Hasil Uji KMO

\begin{tabular}{lll}
\hline No & \multicolumn{1}{c}{ Variabel } & KMO \\
\hline 1 & Kepribadian $(\mathrm{X})$ & 0,836 \\
2 & Kenikmatan Berbelanja (M) & 0,775 \\
3 & Impulse Buying (Y) & 0,760 \\
\hline
\end{tabular}

Sumber: Hasil olahan SPSS, 2017

Kelayakan model uji faktor untuk masing-masing variabel dapat dilihat dari nilai Measures of Sampling Adequancy (MSA). Nilai MSA yang diperoleh dari masing- 
INOBIS: Jurnal Inovasi Bisnis dan Manajemen Indonesia

Volume 1, Nomor 3, Juni 2018

Adelia Christina Purnasari; Ni Made Rastini

masingvariabel dapat diliha tpada Tabel 4. Pada Tabel 4 Nilai MSA masing-masing variabel lebih besar dari 0,5. Artinya masing-masing model layak digunakan dalam analisis faktor.

Tabel 4. Nilai MSA

\begin{tabular}{|c|c|c|c|}
\hline No & Variabel & Item Pernyataan & Nilai MSA \\
\hline \multirow[t]{5}{*}{1} & Kepribadian $(\mathrm{X})$ & $\mathrm{X} 1$ & 0,812 \\
\hline & & $\mathrm{X}_{2}$ & 0,829 \\
\hline & & $\mathrm{X} 3$ & 0,856 \\
\hline & & $\mathrm{X} 4$ & 0,848 \\
\hline & & $\mathrm{X} 5$ & 0,844 \\
\hline \multirow[t]{4}{*}{2} & Kenikmatan Berbelanja(M) & M1 & 0,799 \\
\hline & & M2 & 0,837 \\
\hline & & M3 & 0,732 \\
\hline & & M4 & 0,759 \\
\hline \multirow[t]{4}{*}{3} & Impulse Buying (Y) & Y1 & 0,747 \\
\hline & & $\mathrm{Y}_{2}$ & 0,775 \\
\hline & & Y3 & 0,779 \\
\hline & & Y4 & 0,747 \\
\hline
\end{tabular}

Sumber: Hasil olahan SPSS, 2017

Hasil Percentage of Variance menjelaskan kemampuan dari masing- masing faktor untuk menjelaskan variasinya.Data nilai Percentage of Variance disajikan pada Tabel 5.

Tabel 5.Nilai Percentage of Variance

\begin{tabular}{cllll}
\hline No & & Variabel & $\begin{array}{l}\text { Persentage } \\
\text { Variance }\end{array}$ & of \\
\hline 1 & $\mathrm{X}$ & Kepribadian & 60,081 \\
2 & $\mathrm{M}$ & Kenikmatan Berbelanja & 63,357 \\
3 & $\mathrm{Y}$ & Impulse Buying & 62,882 \\
\hline Sumber: Hasil olahan SPSS, 2017 &
\end{tabular}

Pada Tabel 5 nilai Persentage of Variance masing-masing variabel sudah lebih besar dari 60 persen.Faktor dari masing-masing variabel menunjukkan variabel memiliki kelayakan untuk menjelaskan variabel faktornya.

Tabel 6.Hasil Analisis Jalur 1

\begin{tabular}{llcclll}
\hline & Model & & Unstandardized & \multicolumn{2}{c}{ Standardized } & \\
& & B & $\begin{array}{c}\text { Coefficients } \\
\text { Coefficients }\end{array}$ & & \\
& & Std. Error & Beta & t & Sig. \\
\hline 1 & (Constant) & 0,000 & 0,059 & & 0,000 & 1,00 \\
& & & & & 0 \\
& Kepribadian & 0,756 & 0,059 & 0,756 & 12,795 & 0,00 \\
& & & & & 0 \\
\hline
\end{tabular}


INOBIS: Jurnal Inovasi Bisnis dan Manajemen Indonesia

Volume 1, Nomor 3, Juni 2018

Adelia Christina Purnasari; Ni Made Rastini

\begin{tabular}{ll}
\hline R1 & $: 0,571$ \\
Square & $: 163,713$ \\
F & $: 0,000$ \\
Statistik & \\
Signifikansi & \\
\hline
\end{tabular}

Sumber: Hasil olahan SPSS,2017

Berdasarkan hasil analisis jalur substruktur 1 seperti yang disajikan pada Tabel 6, maka persamaan strukturalnya adalah sebagai berikut.

$\mathrm{M}=\beta 1 \mathrm{X}+\mathrm{e} 1$

$\mathrm{M}=0,756 \mathrm{X}+\mathrm{e} 1$

Tabel 7.Hasil Analisis Jalur 2

\begin{tabular}{|c|c|c|c|c|c|}
\hline Model & $\begin{array}{r}\text { Unst } \\
\text { C }\end{array}$ & $\begin{array}{l}\text { Idardized } \\
\text { fficients }\end{array}$ & $\begin{array}{r}\text { Standardized } \\
\text { Coefficients }\end{array}$ & & \\
\hline & B & Std. Error & Beta & $\mathbf{t}$ & Sig. \\
\hline (Constant) & $-8.3 \mathrm{E}-017$ & 0,046 & & 0,000 & 1,000 \\
\hline Kepribadian & 0,410 & 0,071 & 0,410 & 5,758 & 0,000 \\
\hline $\begin{array}{c}\text { Kenikmatan } \\
\text { Berbelanja }\end{array}$ & 0,505 & 0,071 & 0,505 & 7,088 & 0,000 \\
\hline $\mathbf{R 2}$ & : 0,735 & & & & \\
\hline Square & : 169,084 & & & & \\
\hline $\mathbf{F}$ & : 0,000 & & & & \\
\hline Statistik & & & & & \\
\hline Signifikansi & & & & & \\
\hline
\end{tabular}

Sumber: Hasil olahan SPSS,2017

Berdasarkan hasil analisis jalur substruktur 2 seperti yang disajikan pada Tabel 7,maka persamaan strukturalnya adalah sebagai berikut.

$\mathrm{Y}=\beta 2 \mathrm{X}+\beta 3 \mathrm{M}+\mathrm{e} 2$

$\mathrm{Y}=0,410 \mathrm{X}+0,505 \mathrm{M}+\mathrm{e} 2$

Berdasarkan model substruktur 1 dan substruktur 2, maka dapat disusun model diagram jalur akhir.Sebelum menyusun model diagram jalur akhir, terlebih dahulu dihitung nilai standar eror sebagai berikut.

$$
\begin{aligned}
& \text { Pei }=\sqrt{1-\mathrm{R}_{\mathrm{i}}{ }^{2}} \ldots \ldots \ldots \ldots \ldots \ldots \ldots \ldots \ldots \ldots \ldots \ldots \ldots \ldots \ldots \\
& \mathrm{Pe} 1=\sqrt{1-{R_{1}}^{2}}=\sqrt{ } 1-0,571=0,655 \\
& \operatorname{Pe} 2=\sqrt{1-{R_{2}}^{2}}=\sqrt{ } 1-0,735=0,515
\end{aligned}
$$

Berdasarkan perhitungan pengaruh error (Pei), didapatkan hasil pengaruh error $(\mathrm{Pe} 1)$ sebesar 0,655 dan pengaruh error $(\mathrm{Pe} 2)$ sebesar0,515. Hasil koefisien determinasi total adalah sebagai berikut. 
INOBIS: Jurnal Inovasi Bisnis dan Manajemen Indonesia

Volume 1, Nomor 3, Juni 2018

Adelia Christina Purnasari; Ni Made Rastini

$$
\begin{aligned}
\mathrm{R}^{2} \mathrm{~m} & =1-(\mathrm{Pe} 1)^{2}(\mathrm{Pe} 2)^{2} \ldots \ldots \\
& =1-(0,655)^{2}(0,515)^{2} \\
& =1-(0,429)(0,265) \\
& =1-0,114=0,886
\end{aligned}
$$

Nilai determinasi total sebesar 0,886 mempunyai arti bahwa sebesar 88,6 persen variasi Impulse Buying dipengaruhi oleh variasi Kepribadiandan Kenikmatan Berbelanja, sedangkan sisanya sebesar 11,4 persen dijelaskan oleh faktor lain yang tidak dimasukkan ke dalam model.

Berdasarkan hasil analisis pengaruh kepribadian terhadap kenikmatan berbelanja diperoleh nilai signifikansi sebesar 0,000 dengan nilai koefisien beta 0,756 . Nilai signifikansi $0,000<0,05$ mengindikasikan bahwa $\mathrm{H} 1$ diterima. Hasil ini mempunyai arti bahwa kepribadian berpengaruh positif dan signifikan terhadap kenikmatanberbelanjBerdasarkan hasil analisis pengaruh kepribadian terhadap impulse buying diperoleh nilai signifikansi sebesar 0,000 dengan nilai koefisien beta 0,410. Nilai signifikansi $0,000<0,05$ mengindikasikan bahwa $\mathrm{H} 2$ diterima. Hasilinimempunyai arti bahwa kepribadian berpengaruh positif dan signifikan terhadapimpulse buying.Berdasarkan hasil analisis pengaruh kenikmatan berbelanja terhadap impulse buying diperoleh nilai signifikansi sebesar 0,000 dengan nilai koefisien beta 0,505 . Nilai signifikansi $0,000<0,05$ mengindikasikan bahwa $\mathrm{H} 3$ diterima. Hasil ini mempunyai arti bahwa kenikmatan berbelanja berpengaruh positif dan signifikan terhadap impulse buying.

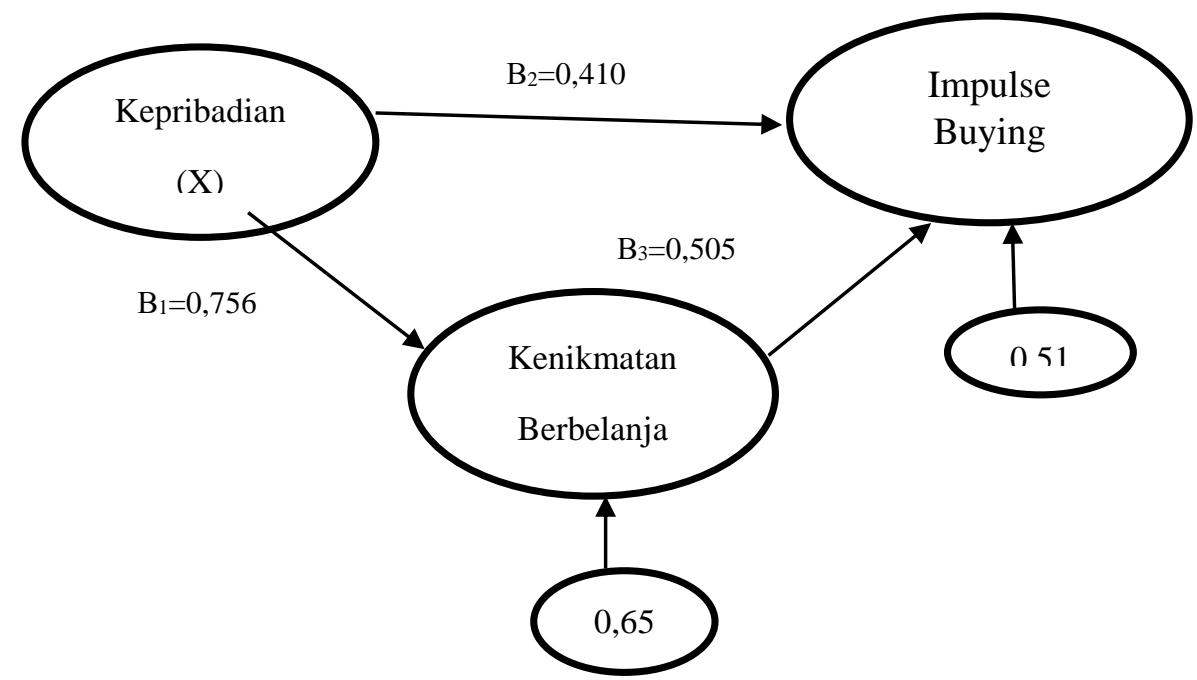

Gambar 3. Validasi Diagram Jalur Akhir

Sumber: data diolah, 2017

Berdasarkan diagram jalur pada Gambar 3, dapat dihitung besarnya pengaruh langsung dan pengaruh tidak langsung serta pengaruh total antar variabel. Perhitungan pengaruh antar variabel dirangkum dalam Tabel 8. 
INOBIS: Jurnal Inovasi Bisnis dan Manajemen Indonesia

Volume 1, Nomor 3, Juni 2018

Adelia Christina Purnasari; Ni Made Rastini

Tabel 8.Pengaruh Langsung dan Pengaruh Tidak Langsung serta Pengaruh Total Kepribadian (X), Kenikmatan Berbelanja (M), dan Impulse Buying (Y)

\begin{tabular}{|c|c|c|c|}
\hline $\begin{array}{l}\text { Pengar } \\
\text { uh } \\
\text { Variab } \\
\text { el }\end{array}$ & $\begin{array}{l}\text { Pengar } \\
\text { uh } \\
\text { Langsun } \\
\text { g }\end{array}$ & $\begin{array}{l}\text { Pengaruh Tidak Langsung } \\
\text { Melalui } \\
\text { Berbelanja } \\
\text { (Y1) } \beta 1 \times \text { xenikmatan }\end{array}$ & $\begin{array}{l}\text { Pengaruh } \\
\text { Total }\end{array}$ \\
\hline $\mathrm{X} \rightarrow \mathrm{M}$ & 0,756 & 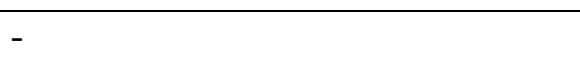 & 0,756 \\
\hline $\mathrm{X} \rightarrow \mathrm{Y}$ & 0,410 & 0,382 & 0,792 \\
\hline $\mathrm{M} \rightarrow \mathrm{Y}$ & 0,505 & - & 0,505 \\
\hline
\end{tabular}

Sumber: Hasil olahan SPSS,2017

Uji sobel merupakan alat analisis untuk menguji signifikansi dari hubungan tidak langsung antara variabel independen dengan variabel dependen yang dimediasi oleh variabel mediator.Hasil perhitungannya adalah sebagai berikut.

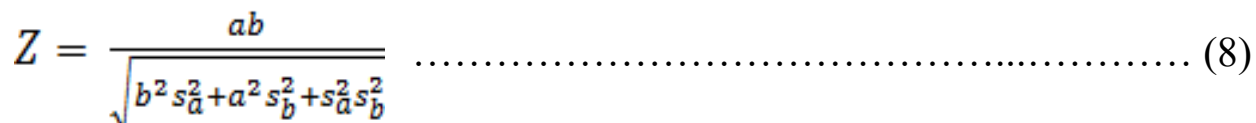

$$
\begin{aligned}
& \mathrm{Z}=\frac{0,756.0,505}{\sqrt{(0,505)^{2}(0,059)^{2}+(0,756)^{2}(0,071)^{2}+(0,059)^{2}}(0,071)^{2}} \\
& Z=6,2044
\end{aligned}
$$

Tabel 9.Hasil Uji Sobel

\begin{tabular}{ll}
\hline Nilai Z & Sig \\
\hline 6,2044 & 0,000 \\
\hline
\end{tabular}

Sumber : Hasil olahan SPSS, 2017

Berdasarkan hasil uji sobel pada Tabel 9 menunjukkan bahwa hasil tabulasi yaitu $\mathrm{Z}=$ $6,20>1,96$ dengan tingkat signifikansi $0,000<0,05$ yang berarti variabel mediator yakni kenikmatan berbelanja dinilai secara signifikansi memediasi hubungan antara kepribadian terhadap impulse buying.

Hasil pengujian menemukan pengaruh positif dan signifikan dari variabel kepribadian terhadap kenikmatan berbelanja, yang berarti $\mathrm{H} 1$ diterima. Hasil penelitian sesuai dengan penelitian sebelumnya oleh Saad dan Metawie (2015) yang menyatakan bahwa secara keseluruhan, hasil penelitian menunjukkan dua faktor kepribadian, yakni kegembiraan dan harga diri secara signifikan berpengaruh positif dengan kenikmatan berbelanja (shopping enjoyment). Hasil serupa juga diperoleh Hart et al. (2006) dan Shen (2012) yang menyatakan bahwafaktor kepribadian berpengaruh positif dan signifikan terhadap kenikmatan yang dirasakan pada saat berbelanja di tempat tertentu. Berdasarkan hasil tersebut ditemukan implikasi bahwa kepribadian berpengaruh positif dan signifikan terhadap kenikmatan berbelanja.Kepribadian konsumen yang semakin konsumtif akan mempengaruhi perilaku kenikmatan berbelanja. Konsumen yang semakin tinggi kepribadiannya seperti rasa percaya diri, konservatif dan ketegasan, maka akan berpotensi meningkatkan perilaku kenikmatan berbelanja pada gerai Stradivarius Beachwalk. 


\section{Adelia Christina Purnasari; Ni Made Rastini}

Berdasarkan hasil pengujian pada hipotesis, ditemukan pengaruh yang positif dan signifikan antara variabel kepribadian terhadap impulse buying, yang berarti $\mathrm{H} 2$ diterima.Hasil penelitian ini didukung oleh penelitian yang dilakukan oleh Sun dan Wu (2011) yang menemukan hasil bahwa pelanggan yang memiliki kepribadian yang terobsesi dengan sifat hedonis diyakini memiliki pengaruh positif terhadap impulse buying.Chuah dan Gan (2015) menyebutkan adanya pengaruh positif dan signifikan antara kepribadian terhadap impulse buying.Penelitian yang dilakukan oleh Mathai dan Haridas (2014) juga mengungkapkan bahwa ada hubungan positif antara kepribadian dan impulse buying. Kepribadian berpengaruh positif dan signifikan terhadap impulse buying, memiliki makna bahwa semakin tinggi kepribadian yang dimiliki oleh konsumen, maka perilaku pembelian yang tidak direncanakan pada gerai stradivarius beachwalk akan semakinmeningkat.

Berdasarkan hasil pengujian pada hipotesis, ditemukan pengaruh yang positif dan signifikan antara variabel kenikmatan berbelanja terhadapimpulsebuying, yang berarti $\mathrm{H} 3$ diterima.Hasil penelitian ini didukung oleh penelitian yang dilakukan oleh Rukhamai (2015) yang menyatakan bahwa kenikmatan berbelanja berpengaruh positif terhadap keputusan pembelian. Kwek et al. (2010), Murti (2012), Mohan et al. (2013) dan Hoch dan Lowenstein (1991) juga memperoleh hasil bahwa kenikmatan berbelanja berpengaruh positif terhadap impulse buying. Hasil penelitian serupa oleh Kim (2010) menyatakan konsumen yang merasakan kenikmatan berbelanja cenderung menunjukkan sikap yang positif untuk melakukan impulse buying. Kenikmatan berbelanja berpengaruh positif dan signifikan terhadap impulse buying, memiliki makna bahwa semakin baik konsumen menikmati suasana saat sedang berbelanja, maka mereka akan membangun sikap yang positif terhadappembelian.

Berdasarkan hasil uji sobel yang telah dilakukan menunjukkan bahwa variabel mediator yakni kenikmatan berbelanja dinilai secara signifikansi memediasi hubungan antara kepribadian terhadap impulse buying. Hasil penelitian ini didukung oleh hasil penelitian yang telah dilakukan oleh Saad dan Metawie (2015) yang berjudul "Store Environment, Personality Factors and Impulse Buying Behavior in Egypt: The Mediating Roles of Shop Enjoyment and Impulse Buying Tendencies" mengatakan bahwa faktor kepribadian seperti kegembiraan dan harga diri serta lingkungan toko secara signifikan terkait dengan perilaku pembelian impulsif. Pembelian secara impulsif muncul untuk memediasi hubungan antara faktor kepribadiandan impulse buyingbehavior.

\section{Simpulan dan Saran}

Simpulan yang dapat diambil berdasarkan hasil analisis adalah kepribadian berpengaruh positif dan signifikan terhadap kenikmatan berbelanja di Stradivarius Beachwalk Kabupaten Badung.Kepribadian berpengaruh positif dan signifikan terhadap impulse buying di Stradivarius Beachwalk Kabupatn Badung.Kenikmatan berbelanja berpengaruh positif dan signifikan terhadap impulse buying di Stradivarius Beachwalk Kabupatn Badung.Kenikmatan berbelanja berpengaruh positif dan signifikan sebagai variabel yang mampu memediasi kepribadian terhadap impulse buying di StradivariusBeachwalk.

Saran yang dapat diberikan berdasarkan hsil analisis adalah pengelola Stradivarius sebaiknya lebih memberikan rasa nyaman saat konsumen berbelanja.Misalnya lebih menekan angka keluhan konsumen yang ragu menyampaikan saat terjadi keluhan saat berbelanja.Sebaliknya bila ada konsumen yang mengeluh dan langsung menyampaikan, itu bisa menjadi acuan perusahaan dalam mengambil keputusan kedepannya.Pihak pengelola 
INOBIS: Jurnal Inovasi Bisnis dan Manajemen Indonesia

Volume 1, Nomor 3, Juni 2018

Adelia Christina Purnasari; Ni Made Rastini

Stradivarius juga harus lebih memperhatikan kenyaman suhu di dalam ruangan demi kenyamanan konsumen.

\section{Referensi}

Beatty, S. E., and Ferrell, M. E. 1998. Impulse Buying: Modeling its precursors. Journal of Retailing, 74(2): pp: 169-191.

Bitner, M.J. 1992. Servicescapes: The Impact of Physical Surroundings on Customers and Employees. Journal of Marketing, 56(2): pp: 57-71.

Chuah, Siew Lin and Chin Chuan Gan. 2015. The Influence of Individual Internal Factors on Impulse Buying Behaviour Through Online Shopping,Global Journal of Business and Social Science Review. 1(1): pp: 60-70.

Fausiana dan Abd Hamid. 2013. Pengaruh Kepribadian Dari Faktor Individu Terhadap Keputusan Pendengar Memilih Lembaga Penyiaran Radio Swasta Di Palembang. Jurnal Politeknik Negeri Sriwijaya, 32(3): Hal: 1- 10.

Hadi, Dewi Rubiyanti. 2004. Pengaruh Store Atmosphere Terhadap Keputusan Pembelian Konsumen Pada China Emporium Factory Outlet Bandung.Skripsi.Fakultas Ekonomi Universitas Widyatama.

Harmancioglu R., Nukhet and Joseph, Zachary Finney Mathew. 2009. Impulse purchases of new products: An empirical analysis. Journal of Product \& Brand Management,18(1): pp: 27-37.

Hart, Cathy., Andrew M. Farrell, Grazyna Stachow, Gary Reed and John W. Cadogan. 2006. Shopping Experience Enjoyment: Impact on Customers' Repatronage Intentions, and Gender Influence. Journal Loughborough University, UK, 23(1): pp: 1-46.

Hausman, Angela. 2000. A multi-method investigation of consumer motivations in Impulse Buying behavior. Journal of Consumer Marketing, 17(5): pp: 403-426.

Hoch, S. J. and Loewenstein, G. F. 1991.Time-inconsistent preferences and consumer selfcontrol.Journal of Consumer Research, 17(2): pp: 492-507.

Kacen, Jacqueline J. and Julie Anne Lee. 2002. The Influence of Culture on Consumer Impulsive Buying Behavior. Journal Of Consumer Psychology, 12(2): pp: 163-176.

Kim, Miyoung. 2010. Psychographic characteristics affecting behavioral intentions towards pop-up retail. International Journal of Retail \& Distribution Management, 38(2): pp:133-154.

Koufaris M. 2002. Applying the Technology Acceptance Model of Flow Theory to Online Consumer Behaviour.Information Systems Research, 13(2): pp: 205-223.

Kwek, Ling Choon., Tan, Piew Hoi., and Lau, Chai Teck. 2010. Investing The Shopping Orientations on Online Purchase Intention in The E-Commerce Environment: A Malaysian Study. Journal of Internet Banking and Commerce, 15(2): pp: 4-5

Mathai, S. T., and Haridas, R. 2014.Personality-its impact on Impulse Buying behaviour among the retail customers in Kochin city.Journal of Business and Management, 16(4): pp: 48-55.

Mohan, Geetha., Sivakumaran, Bharadhwaj and Sharma, Piyush. 2013. Impact of store environment on Impulse Buying behavior. European Journal of Marketing, 47(10): pp. 1711-1732.

Murti, Astri Karina. 2012. Analisis Pengaruh Orientasi Pembelian Terhadap Minat Pembelian Online Studi Kasus: Rajakarcis.com. Skripsi.Fakultas Ekonomi Universitas Indonesia.

Rukhamai, Zulfatur. 2015. Analisis Pengaruh Citra Toko Terhadap Keputusan Pembelian: Studi Kasus Pada Konsumen Indomaret Plus Jalan Soekarno Hatta Malang Jawa Timur. 
INOBIS: Jurnal Inovasi Bisnis dan Manajemen Indonesia

Volume 1, Nomor 3, Juni 2018

Adelia Christina Purnasari; Ni Made Rastini

Thesis.Universitas Islam Negeri Maulana Malik Ibrahim.

Saad, Mohamad., Madiha Metawie. 2015. Store Environment, Personality Factors and Impulse Buying Behavior in Egypt: The Mediating Roles of Shop Enjoyment and Impulse Buying Tendencies. Journal of Business and Management Sciences, 3(2): pp: 69-77.

Sharma, P., Sivakumaran B., and Marshall R. 2010.Impulse Buying And Variety Seeking: A trait-correlates perspective. Journal of Business Research, 63: pp: 276-283.

Shen, Jia. 2012. Social Comparison, Social Presence, and Enjoyment InThe Acceptance Of Social Shopping Websites. Journal of Electronic Commerce Research, 13(3): pp:198212.

Sugiyono. 2012. Metode Penelitian Bisnis. Bandung: Alfabeta Cv.

Sun, T., and $\mathrm{Wu}$, G. 2011. Trait Predictors of Online Impulsive Buying Tendency: A Hierarchical Approach. Journal of Marketing Theory and Practice, 19(3): pp: 337-346. 